\title{
Elementary School Entry: Stress, Competence and Adjustment in First Grade Students
}

\author{
Erica Taciana dos Santos Crepaldi \\ Faculdade de Filosofia, Ciências e Letras de Ribeirão Preto, Universidade de São Paulo, \\ Ribeirão Preto, SP, Brazil \\ Marta Regina Gonçalves Correia-Zanini \\ Centro Universitário das Faculdades Associadas de Ensino - UNIFAE, São Paulo, SP, Brasil \\ Edna Maria Marturano ${ }^{1}$ \\ Faculdade de Medicina de Ribeirão Preto, Universidade de São Paulo, \\ Ribeirão Preto, SP, Brazil
}

\begin{abstract}
This study aimed to compare children from the $1^{\text {st }}$ year of Elementary Education (EE) with or without stress symptoms regarding indicators of adjustment and competence related to academic, social, and behavioral domains, separately for boys and girls. The participants were 85 boys and 72 girls. Twentyfive teachers participated as informants. The children answered the Childhood Stress Scale, the School Hassles Inventory and the academic test Provinha Brasil. The teachers evaluated the social skills and externalizing, and internalizing behavior problems of the children using the Social Skills Rating System. There was no gender difference in self-reported stress symptoms. Girls outperformed boys in the academic achievement test. The teachers rated the girls as more socially skilled and the boys with more externalizing behavior problems. In the comparison of the children with or without stress symptoms, boys with stress were disadvantaged in all variables. Among girls, a similar pattern was found for six out of the 10 variables studied. The results suggest that children that are more competent deal more easily with the transitional requirements of the first year in EE. These children find the adaptive tasks less stressful, which appears to make them less susceptible to the adverse effects of stress.
\end{abstract}

Keywords: Childhood stress, school transition, elementary school, social skills.

\section{No Limiar do Ensino Fundamental: Estresse, Competência e Ajustamento em Alunos do $1^{\circ}$ Ano}

\section{Resumo}

Este estudo objetivou comparar crianças do $1^{\circ}$ ano do Ensino Fundamental (EF), com e sem sintomas de estresse, em indicadores de ajustamento e competência relacionados ao desempenho acadêmico, social e comportamental, separadamente para meninos e meninas. Participaram da pesquisa 85 meninos

Mailing address: Universidade de São Paulo, Faculdade de Medicina de Ribeirão Preto, Departamento de Neurociências e Ciências do Comportamento, Bloco da Saúde Mental, Rua Tenente Catão Roxo, 2650, Ribeirão Preto, SP, Brazil 14051-140. E-mail:emmartur@fmrp.usp.br

This study received financial support from the National Council for Scientific and Technological Development (CNPq), the Coordination for the Improvement of Higher Education Personnel (CAPES) and the São Paulo Research Foundation (FAPESP). The authors thank the children and participating teachers, the families who authorized the participation of their children and the schools that accepted and made possible the study. They also acknowledge the contribution of the psychologists Jessica Castro and Daniele Teixeira in the data collection. 
e 72 meninas, bem como 25 professores, estes como informantes. As crianças responderam à Escala de Stress Infantil e ao Inventário de Estressores Escolares, e realizaram a Provinha Brasil de desempenho acadêmico. Os professores avaliaram as habilidades sociais e os problemas de comportamento externalizantes e internalizantes dos seus alunos com o Social Skills Rating System. Não houve diferença de gênero quanto ao estresse. As meninas obtiveram melhores resultados em desempenho acadêmico e habilidades sociais; os meninos apresentaram mais problemas externalizantes. Na comparação entre crianças com estresse e sem estresse, do mesmo sexo, meninos com estresse estão em desvantagem em todas as variáveis avaliadas. Entre as meninas se verifica tendência semelhante, porém com menos variáveis envolvidas (seis das 10 variáveis). Os resultados sugerem que crianças mais competentes apresentam maior facilidade para se ajustarem às demandas adaptativas da transição. Elas percebem as tarefas adaptativas como menos estressantes, o que supostamente as torna menos expostas aos efeitos adversos do estresse.

Palavras-chave: Estresse infantil, transição escolar, ensino fundamental, habilidades sociais.

\section{En el Umbral dela Escuela Primaria: Estrés, Competencia y el Ajuste de los Estudiantes}

\section{Resumen}

Este estudio comparó los niños de primero año de la Escuela Primaria (EP) con y sin síntomas de estrés en los indicadores de ajuste y de habilidades relacionadas con el rendimiento académico, social y de comportamiento, de forma separada para niños y niñas. Los participantes fueron 157 estudiantes (72 niñas) y sus profesoras $(N=25)$. Los niños respondieron a la Escala de Estrés Infantil, al Inventario Estresores Escolar y llevaron a cabo una prueba de rendimiento académico (Provinha Brasil). Las profesoras evaluaran habilidades sociales, externalización y internalización de sus estudiantes (Social Skills Rating System). No hubo diferencias entre niñas y niños en relación al estrés. Las niñas tuvieron promedios más altos en el rendimiento académico y en las habilidades sociales. Los niños tuvieron más problemas de externalización. Entre los estudiantes del mismo sexo con y sin síntomas de estrés, los niños con estrés están en desventaja en todas las variables. Las niñas presentan tendencias similares, pero con menos variables involucradas (seis de las 10 variables). Los resultados sugieren que los niños más competentes logran mejor adaptarse a las demandas de la transición y perciben las tareas de adaptación como menos estresantes, lo que supuestamente los hace menos expuestos a los efectos adversos del estrés.

Palabras clave: Estrés infantil, transición de la escuela, Escuela Primaria, habilidades sociales.

The traditional notion of childhood as a period free of external demands, responsibilities and stress has been confronted in recent decades by research on childhood stress (Byrne, Thomas, Burchell, Olive, \& Mirabito, 2011). According to Lipp (2000), in the course of the intellectual, emotional and affective development of children, they are faced with challenging situations that may exceed their still immature ability to cope with them, making them vulnerable to stress.

According to Lipp and Lucarelli (2008), childhood stress is similar to that of adults and involves a reaction of the body with physical (headaches, abdominal pain, appetite changes, diarrhea, stuttering, etc.) and /or psychological components (depression, anxiety, tantrums, excessive crying, night terrors, etc.) when confronted with any stimulus that annoys, frightens and/or makes the person happy, that is, any new fact that requires adaptation. The authors propose to evaluate stress according to a set of symptoms present and their stage of development: stages of Alert or Alarm, Defense or Resistance, Near-exhaustion and Exhaustion, 
considered the most acute stage of stress. Brazilian studies on the evaluation and incidence of childhood stress are scarce; however, three surveys conducted in the school context indicate a certain prevalence of stress, worthy of attention. In the study of Vilela (1995) 40 students from the $1^{\text {st }}$ to $4^{\text {th }}$ grade of elementary education (EE) of public and private schools were evaluated, with $62 \%$ of them presenting symptoms of stress, mostly in the alert stage. Tanganelli and Lipp (1998) evaluated 158 students from the $1^{\text {st }}$ to $4^{\text {th }}$ grade and identified symptoms consistent with the presence of stress in $55 \%$ of the sample. Finally, the study by Enumo, Ferrão and Ribeiro (2006) presented indications of stress in $21 \%$ of the 60 students, aged 8 and 14 years, evaluated. Investigations into stress, in both adults and children, have highlighted that the daily tensions have greater power for predicting symptoms and psychological disorders than unpredictable, uncontrollable, exceptional and traumatic life events (Bridley \& Jordan, 2012). The daily tensions, known in the literature as "daily hassles" comprise annoying, frustrating and distressing demands that, to some extent, characterize the daily transactions with the environment, which may affect the physical and emotional well-being of adults, adolescents and children (Bridley \& Jordan, 2012; Escobar et al., 2013; Kanner, Coyne, Schaefer, \& Lazarus, 1981).

Among the main sources of daily hassles in childhood is the school, where children spend much of their time. The school is seen by many students as a major source of daily hassles (Eriksson \& Sellströn, 2010; Rende \& Plomin, 1992). The hassles of the school environment are present in the academic requirements, in the relationships with colleagues and teachers, in the lower grades and in the realization of many after school activities (Escobar et al., 2013; Vanaelst, De Vriendt, Huybrechts, Rinaldi, \& De Henauw, 2012).

Daily hassles at school have been associated with stress symptoms in different cultures. In Sweden, Hjern, Alfven and Östberg (2008) found a strong association between the perception of school hassles and psychosomatic complaints in children and adolescents aged 10 to 18 years, while Eriksson and Sellströn (2010), with students from 11 to 15 years of age, identified the perception of academic requirements as a predictor of subjective health complaints. In the study of Hesketh et al. (2010), carried out with 1,291 Chinese children aged between nine and 12 years, the participants identified multiple stressors at school, with all the stressors being significantly associated with psychosomatic symptoms. In research conducted with Brazilian children attending the former $1^{\text {st }}$ grade of elementary education, Trivellato-Ferreira and Marturano (2008) found a positive correlation between stress symptoms and the perception of everyday hassles at school.

In addition to the hassles commonly present in the school environment, there seems to be an increased vulnerability to stress in moments of school transition (Marturano, 2008). Specifically, entering EE configures the transition between the pre-school and school stages, when the child is faced with the developmental tasks of the new stage: to succeed in academic learning, to form friendships with peers and to adhere to the norms of society for moral conduct and prosocial behavior, among others (Masten \& Coatsworth, 1998).

Furthermore, the challenges of entering elementary education are not limited to the requirements of the school age developmental tasks. The change of school level leads to important adaptive tasks, prominent among which are coping with a new environment, relating to unknown adults, gaining acceptance in a new group of peers and fulfilling the requirements of the student role, translated into adult expectations and formalized through periodic progress reviews. These tasks become even more challenging when the child did not attend early childhood education (ECE), or when, even having attended, needed to change school to join EE (Marturano, 2008; TrivellatoFerreira \& Marturano, 2008). A relevant research topic must be, then, the question of the possible effects of this combination of challenges on the adaptive functioning of the child who joins EE. 
Adaptive functioning in childhood can be evaluated in terms of competence and dysfunction. Competence refers to the degree to which the child is efficiently able to resolve the developmental tasks and challenges present in the environment, resulting in good adaptation, although not necessarily excellent performance. Dysfunction results in problems in the adaptive functioning, comprising the recurring difficulty of maintaining behaviors of self-control (Gardinal-Pizato, Marturano, \& Fontaine, 2014; Masten \& Coatsworth, 1998).

Studies on childhood competence in the EE years have investigated the academic and social domains due to the relevance of these for school age developmental tasks (Chen, Huang, Chang, Wang, \& Li, 2010; Correia-Zanini, 2013). Competence in the academic area is commonly estimated by objective tests of scholastic skills and evaluation by the teacher (Correia-Zanini, 2013). Regarding the social domain, competence is often operationalized through the social skills construct, which includes a set of behaviors classes presented by individuals in social situations that provide a healthy and productive interpersonal relationship and imply some control of their own emotions (Gardinal-Pizato et al., 2014). Examples of social skill classes are assertiveness, solving interpersonal problems, cooperation, empathy, emotional expressiveness and academic social skills (Del Prette \& Del Prette, 2005; Gardinal-Pizato et al., 2014).

Regarding the indicators of dysfunctions, these have been operationalized by the term behavioral adjustment that, in turn, is associated with two broad factors: externalizing and internalizing behaviors. The externalizing behaviors include problems with attention and self-regulation, and antisocial and aggressive behavior, while internalizing behaviors include depression, anxiety, isolation, feelings of inferiority and somatic complaints (Achenbach \& Edelbrock, 1979).

In an attempt to identify conditions associated with the impact of the initial demands of $\mathrm{EE}$ on the adaptive functioning of the students, it can be assumed that children with more favorable indicators of adaptive functioning would be more protected from these demands, while children with poorer functioning would be more vulnerable to the stress of transition. These relationships are suggested by the results of the study by Trivellato-Ferreira and Marturano (2008), who found, in children who began EE, negative correlations between stress symptoms and measures of academic competence and adjustment. In addition, from the above and the literature on gender differences, boys would be more vulnerable to stress in the early years of EE, as in this stage of schooling they present poorer academic performance (Grimm, Steele, Mashburn, Burchinal, \& Pianta, 2010; Matthews, Kizzie, Rowley, \& Cortina, 2010), less developed social skills (Bandeira, Rocha, Freitas, Del Prette, \& Del Prette, 2006; Matthews et al., 2010) and more externalizing behavior problems (Fanti \& Henrich, 2010; Robbers et al., 2010; Silver, Measelle, Armstrong, \& Essex, 2010). However, there is also some empirical evidence that girls in general report more symptoms of stress (Lipp, Arantes, Buriti, \& Witzig, 2002), although this evidence is not consensual (Pacanaro \& Di Nucci, 2005).

The present study falls within this context, with the aim to compare children of the $1^{\text {st }}$ year of EE evaluated with and without symptoms of stress in relation to academic performance, social skills, behavioral problems and perception of school hassles. Children considered to present symptoms of stress were those who were in any of the four stages of stress, according to the model suggested by Lipp and Lucarelli (2008) in their Childhood Stress Scale - CSS, while children without stress were those that did not present any of these stages. It should be noted that this is not a diagnosis of stress symptoms at a clinical level, but the presence of some stage of stress.

The working hypothesis was that children with stress would present lower academic performance, fewer social skills, more behavior problems and higher perception of school hassles in relation to the children without stress. Given the gender differences identified in the literature, associations with this variable were preliminar- 
ily investigated; furthermore, the hypothesis was tested separately for boys and girls.

\section{Method}

\section{Ethical Considerations}

This study is part of a project approved by the Research Ethics Committee of Faculdade de Filosofia, Ciencias e Letras de Ribeirao Preto at the Universidade de Sao Paulo. It meets the standards set out in Resolution No. 196/96 of Comissão Nacional de Ética em Pesquisa (CONEP) and the provisions of Resolution No. 016/2000 of the Federal Council of Psychology. The adult participants signed the consent form and, in the case of the child participants, one of those responsible signed the consent form, with the participant having given prior verbal consent.

\section{Participants}

The original sample was constituted by drawing lots in 25 classes of the $1^{\text {st }}$ year of EE, in municipal schools of a city in the interior of São Paulo with approximately 111,000 inhabitants (Correia-Zanini, 2013). In each class, 13 students were randomly selected, resulting in an assumed sample of 325 participants. All those responsible were consulted and 181 gave their consent for the participation of the child. A total of 157 students of this sample, who met the criterion of two years of previous experience in ECE, participated in this study, with 85 boys and 72 girls, aged between five years and eight months and seven years and six months (mean 6 years and 10 months, SD 4 months). A total of 25 of their respective teachers of the $1^{\text {st }}$ year of EE also participated in the study, as informants.

\section{Site}

Data were collected in seven of the $15 \mathrm{mu}-$ nicipal schools that provide EE. The selection of the schools was performed together with technicians of the municipal education department, aiming to represent different regions of the city, with one school in the central region, two near the center and four in outer neighborhoods, totaling 25 classes.

\section{Instruments}

Childhood Stress Scale - CSS. The CSS aims to identify how often children aged six to 14 years experience symptoms of stress and what kind of reaction characterizes these symptoms (Lipp \& Lucarelli, 2008). The scale consists of 35 items, each accompanied by a Likert type, analog scale, circle-shaped divided into quadrants. The score corresponds to the number of circle quadrants that the child fills in. Not filling in the circle corresponds to - never happens - 0 points; filling in one part - happens a little - 1 point; filling in two parts - sometimes happens, 2 points; filling in three parts - almost always happens- 3 points; filling in 4 parts - always happens - 4 points. The sum of points of all the items results in the total score of symptoms presented by the child. With this score it is also possible to identify the stage of the stress: 0 to 39.5 - no stress; 39.6 to 59.4 - alert stage; 59.5 to 79.4 points - resistance stage; 79.5 to 99.3 or seven circles with all the parts filled in - near exhaustion stage; above 99.3 - exhaustion stage. In the present study, a dichotomous classification was used between scores 39.5 and 39.6 to discriminate children without symptoms of stress and children with symptoms in the alert, resistance, near exhaustion or exhaustion stages.

Provinha Brasil 2009. The evaluation called Provinha Brasil was developed by the National Institute for Educational Studies and Research "Anísio Teixeira" (INEP, 2009) and aims to diagnose the level of literacy of children enrolled in the $2^{\text {nd }}$ year of EE of Brazilian public schools. It consists of an example question that shows the students how they should respond in the test and another 24 multiple-choice questions formulated to evaluate performance. The evaluative questions are sequenced in increasing levels of demand for skills, from the most basic to the most advanced. The questions are of three types: Type 1 - Questions where the commands and alternatives need to be fully read by the applicator; Type 2 - Questions of which the applicator reads only the commands; Type 3 - Questions where the applicator reads only the initial guidance to warn students that they have to read the text, the 
statements and alternatives alone. Each correctly answered question receives one point and the total score is related to the sum of the items that the child answers correctly, varying, therefore, between 0 and 24 (http://provinhabrasil.inep. gov.br).

Social Skills Rating System. The Brazilian adaptation of the Social Skills Rating System SSRS-BR - Teacher version was used (Bandeira, Del Prette, Del Prette, \& Magalhães, 2009). The questionnaire for teachers includes three scales: social skills, with five factors (cooperation with peers, positive assertion, responsibility/cooperation, self-defense and self-control); behavior problems in two factors (internalizing and externalizing); and academic competence, consisting of nine items, not used in this study. To evaluate the frequency of social skills and behavior problems there are three possible answers: "never" (0), "sometimes" (1) and "very often" (2). The total score of each scale or factor is the result of the sum obtained from the corresponding items. Bandeira et al. (2009) reported satisfactory levels of internal consistency and temporal stability for the Brazilian adaptation of the scales. The factor structure used in this study was obtained through Confirmatory Factor Analysis performed by Correia-Zanini (2013).

School Hassles Inventory - SHI. The SHI aims to investigate disturbing or irritating situations related to school life in four domains: school performance, family-school relations, relations with peers and other demands of school life (Marturano \& Gardinal, 2008; TrivellatoFerreira \& Marturano, 2008). Presented individually to the child, it consists of thirty items. For each situation presented, the child responds to what happened to him/her during the school year; if it has happened, also saying how the situation bothered $\mathrm{him} / \mathrm{her}$. To measure the exposure to the hassles, a value of zero is assigned to the item that did not occur, according to the child, and one for the situation that did occur. To measure the impact, each item receives an increase of zero, one, two or three points, in accordance with the intensity of the effect reported by the child, on a four point scale: nothing, just a little, more or less, a lot. In this study, the SHI was used with the two dimension factor structure, identified by Gardinal-Pizato (2010) and revised by Correia-Zanini (2013): (a) hassles associated with the student role, with 10 items related to school performance, family-school relationship and the teacher; (b) hassles derived from the interpersonal relationships at school, with 7 items of the relationships with peers and adults.

\section{Procedure}

Data collection with the children and teachers took place in November and December 2010, during class hours and in spaces assigned by the schools. The children answered the SHI and CSS instruments individually. The Provinha Brasil was applied collectively by the second author with the help of a technical support assistant, in classes of 5 to 20 students, according to the space available for the activity. The teachers were instructed to complete the forms of the SSRS.

For the formation of the with and without stress groups, the percentage distributions of students in each stress stage were calculated, from the Childhood Stress Scale. The percentage distributions by stages of stress were as follows: no stress, $42.7 \%(n=67)$; alert stage, $11.5 \%$; resistance stage, $1.9 \%$; near exhaustion stage, $42.7 \%$; exhaustion stage, $1.3 \%$. The two groups were formed according to the presence of stress symptoms, resulting in 90 children in the stress group (57\%) and 67 in the without stress group. The groups were compared in terms of distribution and gender using the chi-square test. Once the assumptions for using parametric statistics were confirmed, Student's $t$-test was applied, adopting the significance level of $p<.05$, to compare them with respect to academic performance, social skills, behavior problems and perception of school hassles. To measure the magnitude of effect between the comparisons, the calculation of Cohen's $d$ was used, with the following magnitude bands, in accordance with Marôco (2011, p. 251): small when $d \leq .2$; medium, when $d$ ranges between .2 and .5 ; large when $d$ is between .5 and 1.0; very large when $d>1.0$. 


\section{Results}

There was no significant difference between girls and boys in relation to the presence of stress (girls $51 \%$, boys $62 \% ; \chi^{2}(1)=0.422$, $p>.05$ ). Table 1 presents the results of the other comparisons between the genders. The table shows the means and standard deviation for boys and girls, as well as the $t$-values and the associated probabilities.

Table 1

Comparison between Boys and Girls in the Variables Evaluated in the $1^{\text {st }}$ Year

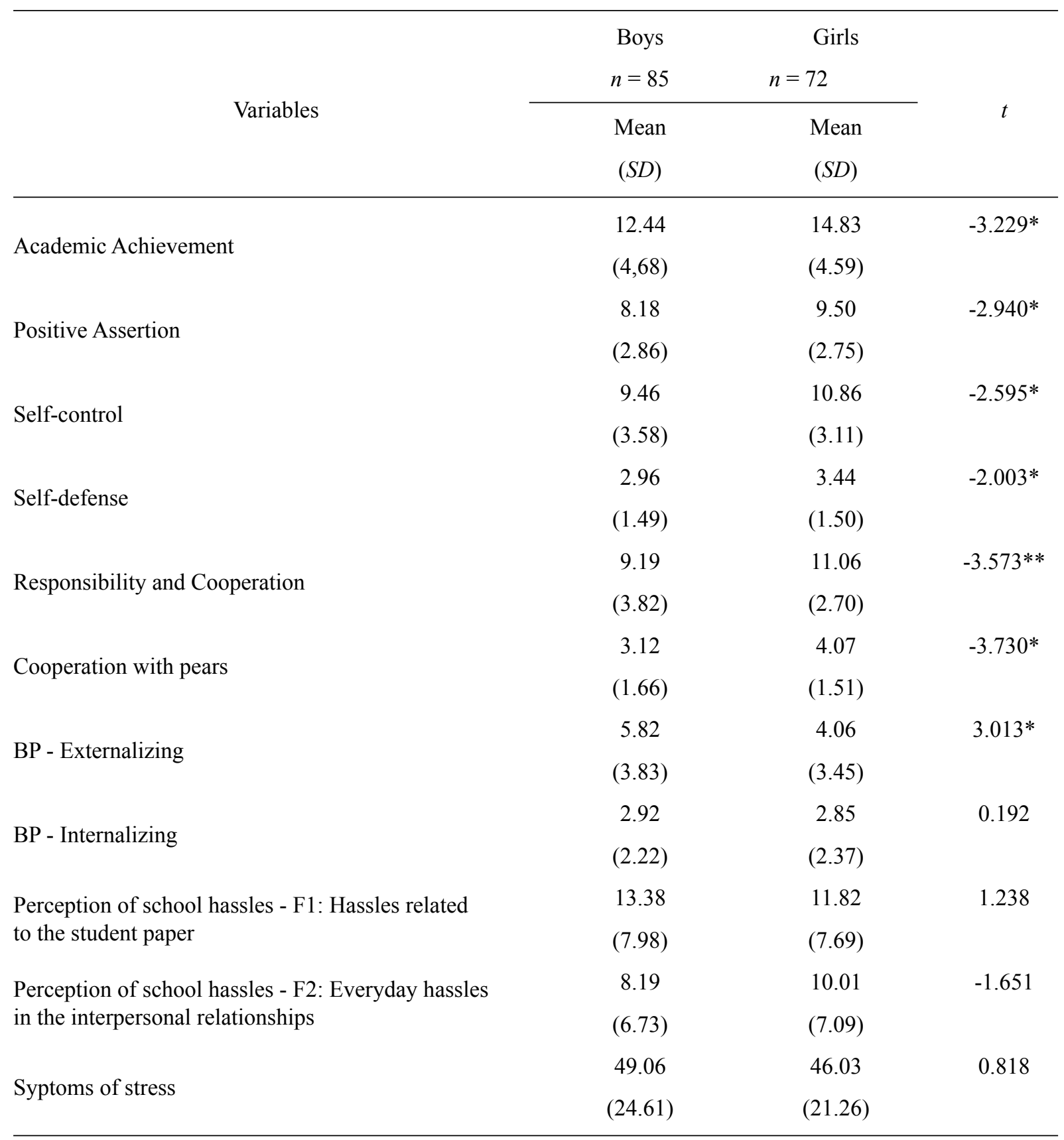

Note. ${ }^{*} p<.05 ;{ }^{* *} p<.001$.

The results in Table 1 indicate gender differences in the variables related to academic performance and social skills. The group of girls presented higher means in academic performance, with a medium effect size $(d=-.52)$, and in all assessed social skills, with responsibility and cooperation with peers showing large effect sizes (-.56 and .60, respectively), and the other skills 
medium sizes, with $d=-.32$ for self-defense, $d=$ .42 for self-control and $d=-.47$ for positive assertion. The groups were also differentiated by externalizing behavior, with the highest mean for the boys $(d=.48)$. There were no differences in the measures of internalization and perceived hassles.

The results of the comparisons between children with and without stress are shown in Tables 2 and 3 respectively for boys and girls.

Table 2

Comparison between Boys with and Without Stress in the Other Variables Evaluated in the $1^{\text {st }}$ Year

\begin{tabular}{|c|c|c|c|}
\hline \multirow{2}{*}{ Variables } & $\begin{array}{c}\text { With stress } \\
n=53\end{array}$ & $\begin{array}{l}\text { Without stress } \\
\qquad n=32\end{array}$ & \multirow[t]{2}{*}{$t$} \\
\hline & $\begin{array}{l}\text { Mean } \\
(S D)\end{array}$ & $\begin{array}{l}\text { Mean } \\
(S D)\end{array}$ & \\
\hline \multirow{2}{*}{ Academic achievement } & 11.23 & 14.44 & $-3.236^{*}$ \\
\hline & $(4.25)$ & $(4.72)$ & \\
\hline \multirow{2}{*}{ Positive Assertion } & 7.57 & 9.19 & $-2.617 *$ \\
\hline & $(2.78)$ & $(2.74)$ & \\
\hline \multirow{2}{*}{ Self-control } & 8.68 & 10.75 & $-2.676^{*}$ \\
\hline & (3.89) & $(2.58)$ & \\
\hline \multirow{2}{*}{ Self-defense } & 2.70 & 3.41 & $-2.167^{*}$ \\
\hline & $(1.46)$ & $(1.46)$ & \\
\hline \multirow{2}{*}{ Responsibility and Cooperation } & 8.06 & 11.06 & $-3.781 * *$ \\
\hline & $(3.81)$ & $(3.07)$ & \\
\hline \multirow{2}{*}{ Cooperation with peers } & 2.74 & 3.75 & $-2.846^{*}$ \\
\hline & $(1.58)$ & $(1.60)$ & \\
\hline \multirow{2}{*}{ BP - Externalizing } & 6.94 & 3.97 & $3.722 * *$ \\
\hline & $(3.88)$ & $(2.98)$ & \\
\hline \multirow{2}{*}{ BP - Internalizing } & 3.30 & 2.28 & $2.093 *$ \\
\hline & $(2.32)$ & $(1.92)$ & \\
\hline \multirow{2}{*}{$\begin{array}{l}\text { Perception of school hassles - F1: Hassles related } \\
\text { to the student paper }\end{array}$} & 15.36 & 10.09 & $3.093 *$ \\
\hline & $(8.05)$ & $(6.78)$ & \\
\hline \multirow{2}{*}{$\begin{array}{l}\text { Perception of school hassles - F2: Everyday hassles } \\
\text { in the interpersonal relationships }\end{array}$} & 10.04 & 5.13 & $3.467 * *$ \\
\hline & $(6.51)$ & $(6.02)$ & \\
\hline
\end{tabular}

Note. ${ }^{*} p<.05 ;{ }^{* *} p<.001$.

As shown in Table 2, boys with stress were at a disadvantage in all variables evaluated, compared to their peers without stress. They had lower means, with large effect size, in the academic performance indicator $(d=-.71)$ and in the social skills of positive assertion $(d=-$
$.59)$, self-control ( $d=-.63)$ responsibility and cooperation $(d=-.87)$ and cooperation with peers ( $d=-.64)$. For the self-defense social skill, they also presented a lower mean, however, with a medium effect size $(d=-.49)$. In measures of externalizing behavior $(d=.86)$, hassles 
Table 3

Comparison between Girls with and Without Stress in the Other Variables Evaluated in the $1^{\text {st }}$ Year

\begin{tabular}{|c|c|c|c|}
\hline \multirow[b]{2}{*}{ Variables } & $\begin{array}{l}\text { With stress } \\
\qquad n=37\end{array}$ & $\begin{array}{l}\text { Without stress } \\
\qquad n=35\end{array}$ & \multirow[t]{2}{*}{$t$} \\
\hline & $\begin{array}{l}\text { Mean } \\
(S D)\end{array}$ & $\begin{array}{l}\text { Mean } \\
(S D)\end{array}$ & \\
\hline \multirow{2}{*}{ Academic achievement } & 13.43 & 16.31 & $-2.787 *$ \\
\hline & $(3.86)$ & $(4.88)$ & \\
\hline \multirow{2}{*}{ Positive Assertion } & 9.27 & 9.74 & -0.727 \\
\hline & $(2.68)$ & $(2.83)$ & \\
\hline \multirow{2}{*}{ Self-control } & 9.76 & 12.03 & $-3.342 * *$ \\
\hline & $(3.39)$ & $(2.31)$ & \\
\hline \multirow{2}{*}{ Self-defense } & 3.38 & 3.51 & -0.382 \\
\hline & $(1.52)$ & $(1.50)$ & \\
\hline \multirow{2}{*}{ Responsibility and Cooperation } & 10.30 & 11.86 & $-2.558^{*}$ \\
\hline & $(2.87)$ & $(2.29)$ & \\
\hline \multirow{2}{*}{ Cooperation with peers } & 4.08 & 4.06 & -0.067 \\
\hline & $(1.46)$ & $(1.59)$ & \\
\hline \multirow{2}{*}{ BP - Externalizing } & 5.00 & 3.06 & $2.472 *$ \\
\hline & $(3.86)$ & $(2.67)$ & \\
\hline \multirow{2}{*}{ BP - Internalizing } & 3.05 & 2.63 & 0.761 \\
\hline & $(2.37)$ & $(2.38)$ & \\
\hline \multirow{2}{*}{$\begin{array}{l}\text { Perception of school hassles - F1: Hassles related } \\
\text { to the student paper }\end{array}$} & 14.59 & 8.89 & $3.368^{* *}$ \\
\hline & $(7.79)$ & $(6.49)$ & \\
\hline \multirow{2}{*}{$\begin{array}{l}\text { Perception of school hassles - F2: Everyday hassles } \\
\text { in the interpersonal relationships }\end{array}$} & 11.95 & 7.97 & $2.458^{* *}$ \\
\hline & $(7.59)$ & $(5.98)$ & \\
\hline
\end{tabular}

Note. ${ }^{*} p<.05 ;{ }^{* *} p<.001$.

related to the student role $(d=.71)$ and daily hassles in interpersonal relationships $(d=.78)$, they presented higher means with significant differences and large effect size. For internalizing behaviors the difference showed a medium effect size $(d=.48)$.

A similar trend was verified among the girls, however, with fewer variables involved, all with large effect size. The results in Table 3 show the presence of stress associated with poorer academic performance $(d=-.65)$, fewer social skills of self-control ( $d=-.78)$ and responsibility/ cooperation $(d=-.60)$, more externalizing behavior problems $(d=-.58)$ and a perception of greater impact of school hassles related to the student role $(d=-.80)$ and interpersonal relationships $(d=-.58)$. The groups did not differ in some indicators assessed by the teacher in the SSRS: social skills (positive assertion, self defense and cooperation with peers) and internalizing behavior problems. 


\section{Discussion}

This study focused on stress of the child in the $1^{\text {st }}$ year of EE. The aim was to compare children of the $1^{\text {st }}$ year of EE evaluated with and without symptoms of stress, separately for boys and girls, in relation to academic performance, social skills, behavioral problems and perception of school hassles. The hypothesis was that children with stress would present lower academic performance, fewer social skills, more behavior problems and higher perception of school hassles in relation to the children without stress.

In the composition of the groups, it was found that $57 \%$ of $1^{\text {st }}$ year students presented symptoms of stress at some level, $43 \%$ at the stage of near exhaustion, one of the most severe stages of stress (Lipp \& Lucarelli, 2008). This index is worrying because the sample was composed only of children who had attended ECE, a condition that attenuates the effects of stress associated with the transition. The literature indicates that passing from ECE is associated with higher levels of performance and adjustment of the child in the results of the first year of EE and greater acceptance by peers, with these evaluations corresponding to a subjective experience of less stress related to the school (Marturano \& Gardinal, 2008; Pereira, Marturano, GardinalPizato, \& Fontaine, 2011; Trivellato-Ferreira \& Marturano, 2008).

There was no significant difference between boys and girls in relation to the presence of stress symptoms. This result is consistent with those obtained by other authors who also used the Childhood Stress Scale to evaluate symptoms of stress in school, either in the $1^{\text {st }}$ (TrivellatoFerreira $\&$ Marturano, 2008) or the $4^{\text {th }}$ grade of the former EE of eight years (Pacanaro \& Di Nucci, 2005). Conversely, it differs from the result obtained by Lipp et al. (2002) in a sample of schoolchildren aged 7 to 14 , in the context of EE of eight years. There were, however, gender differences in the variables related to academic performance, social skills and the measure of externalizing behavior.

Confirming results of previous studies with EE students, the girls presented higher means in academic performance (Grimm et al., 2010; Matthews et al., 2010) and in all evaluated social skills (Bandeira et al., 2006; Matthews et al., 2010). The boys presented more externalizing behavior problems, which also corresponds to previously established evidence (Fanti \& Henrich, 2010; Robbers et al., 2010; Silver et al., 2010). From the perspective of adaptive functioning in childhood (Gardinal-Pizato et al., 2014; Masten \& Coatsworth, 1998), these results indicate greater difficulty of the boys in adapting to the tasks of the $1^{\text {st }}$ year of EE. The issue is covered later in this discussion.

The hypothesis formulated in the introduction was widely confirmed. In both genders, the presence of stress was inversely associated with academic performance and social skills and directly associated with behavior problems. The inverse relationship between competence and stress found in both genders is in line with the theoretical model presented in the introduction and agrees with the findings of the study conducted by Trivellato-Ferreira and Marturano (2008) with students of the former $1^{\text {st }}$ grade, which indicated an inverse relationship of symptoms of stress with academic achievement and adjustment. Accordingly, the results of this study confirm that children that are more competent find it easier to adjust to the adaptive requirements of the transition and, consequently, perceive the adaptive tasks as less stressful, which makes them less exposed to the adverse effects of stress (Marturano, 2008).

The interpretation of a mediator role of the perception of hassles in the relationship between adaptive difficulties and symptoms of stress is indirectly supported by the results, which indicated an association between perception of hassles and stress symptoms. In both genders, there was an association of the presence of stress with the perception of school hassles in two factors, in relation to the role of student and in the interpersonal relationships. These results confirm the association already established between exposure to school hassles and stress symptoms (Hesketh et al., 2010; Hjern et al., 2008; Trivellato-Ferreira \& Marturano, 2008). 
At this point of the discussion, the question is again raised of a possible greater difficulty for boys in adapting to the tasks of the $1^{\text {st }}$ year of EE. According to the line of interpretation developed here, if boys were indeed less adapted to the demands of the $1^{\text {st }}$ year, they would present more symptoms of stress, which did not occur. However, the association between the presence of stress and indicators of performance of adaptive tasks was more pronounced in the male group. As shown in Tables 2 and 3, among the boys all 10 variables investigated significantly differentiated the groups with and without stress in the direction expected, while among the girls six variables were associated with stress in the direction predicted. It seems, therefore, that the processes involved in the transition of the $1^{\text {st }}$ year of EE differ between boys and girls, however, their description requires complex models that go beyond differences in the level of stress symptoms reported by the children.

Although the methodological choices of this study achieved its main aim, their limitations may have contributed to the persistence of gaps regarding the investigation of the association of stress with gender. In order to fill them, further studies are suggested that adopt a prospective design, with tests of stress prediction models compatible with the complexity envisioned in this study. It may also be useful to use other stress evaluation methods, such as, for example, a clinical diagnosis of stress or a separate identification of the phases of its evolution, as proposed by Lipp and Lucarelli (2008).

Another limitation of this study refers to the sample, composed only of students from municipal schools. In order to increase the power of generalization of the results, it is recommended that further studies include students from other schools, such as state and private schools, in the sample.

Finally, given the high rate of stress symptoms in the sample, the findings suggest a demand for interventions aimed at preventing problems associated with stress in schoolchildren. By identifying conditions associated with the presence of stress, the results also provide subsidies for these practices, with emphasis on the promotion of social skills. It also seems fundamental to develop coping strategies so that the child can cope with everyday school hassles, a major source of stress, with repercussions for the emotional health of students in EE (Eriksson \& Sellströn, 2010), particularly among young people, as a risk factor for depression and anxiety (Byrne et al., 2011). However, investigations are necessary to clarify the processes involved in these associations, testing prediction models with the power to detect different directions of effects between the variables studied.

\section{References}

Achenbach, T. M., \& Edelbrock, C. S. (1979). The child behavior profile: II. Boys aged 12-16 and girls aged 6-11 and 12-16. Journal of Consulting and Clinical Psychology, 47(2), 223-233. doi:10.1037/0022-006X.47.2.223

Bandeira, M., Del Prette, Z. A. P., Del Prette, A., \& Magalhães, T. (2009). Validação das escalas de habilidades sociais, comportamentos problemáticos e competência acadêmica (SSRR-BR) para o ensino fundamental. Psicologia: Teoria e Pesquisa, 25(2), 271-282. doi:10.1590/S010237722009000200016

Bandeira, M., Rocha, S. S., Freitas, L. C., Del Prette, Z. A. P., \& Del Prette, A. (2006). Habilidades sociais e variáveis sociodemográficas em estudantes do ensino fundamental. Psicologia em Estudo, 11(3), 541-549. doi:10.1590/S141373722006000300010

Bridley, A., \& Jordan, S. S. (2012). Child routines moderate daily hassles and children's psychological adjustment. Children's Health Care, 41(2), 129-144. doi:10.1080/02739615.2012.65 7040

Byrne, D. G., Thomas, K. A., Burchell, J. L., Olive, L. S., \& Mirabito, N. S. (2011). Stressor experience in primary school-age children: Development of a scale to assess profiles of exposure and effects on psychological well-being. International Journal of Stress Management, 18(1), 88-111. doi:10.1037/a0021577

Chen, X., Huang, X., Chang, L., Wang, L., \& Li, D. (2010). Aggression, social competence, and academic achievement in Chinese children: A 5-year longitudinal study. Development and Psychopathology, 22(3), 583-592. doi:10.1017/ S0954579410000295 
Correia-Zanini, M. R. G. (2013). Um estudo prospectivo sobre o percurso escolar de crianças nos primeiros anos do ensino fundamental (Doctoral dissertation). Retrieved from http://www. teses.usp.br/teses/disponiveis/59/59137/tde06012014-100239/

Del Prette, Z. A. P., \& Del Prette, A. (2005). Psicologia das habilidades sociais na infância: Teoria e prática. Petrópolis, RJ: Vozes.

Enumo, S. R. F., Ferrão, E. S., \& Ribeiro, M. P. L. (2006). Crianças com dificuldade de aprendizagem e a escola: Emoções e saúde em foco. Estudos de Psicologia (Campinas), 23(2), 139-149. doi:10.1590/S0103-166X2006000200004

Eriksson, U., \& Sellström, E. (2010). School demands and subjective health complaints among Swedish schoolchildren: A multilevel study. Scandinavian Journal of Public Health, 38(4), 344-350. doi:10.1177/1403494810364683

Escobar, M., Alarcón, R., Blanca, M. J., FernándezBaena, F. J., Rosel, J. F., \& Trianes, M. V. (2013). Daily stressors in school-age children: A multilevel approach. School Psychology Quartely, 28(3), 227-238. doi:10.1037/spq0000020

Fanti, K. A., \& Henrich, C. C. (2010). Trajectories of pure and co-occurring internalizing and externalizing problems from age 2 to age 12: Findings from the National Institute of Child Health and Human Development Study of Early Child Care. Developmental Psychology, 46(5), 1159-1175. doi:10.1037/a0020659

Gardinal-Pizato, E. C. (2010). Um estudo longitudinal de trajetórias de desempenho escolar (Unpublished doctoral dissertation, Universidade de São Paulo, Ribeirão Preto, SP, Brazil).

Gardinal-Pizato, E. C., Marturano, E. M., \& Fontaine, A. M. G. V. (2014). Trajetórias de habilidades sociais e problemas de comportamento no ensino fundamental: Influência da educação infantil. Psicologia: Reflexão e Crítica, 27(1), 189-197. doi:10.1590/S0102-79722014000100021

Grimm, K. J., Steele, J. S., Mashburn, A. J., Burchinal, M., \& Pianta, R. C. (2010). Early behavioral associations of achievement trajectories. Developmental Psychology, 46(5), 976-983. doi:10.1037/a0018878

Hesketh, T., Zhen, Y., Lu, L., Dong, Z. X., Jun, Y. X., \& Xing, Z. W. (2010). Stress and psychosomatic symptoms in Chinese school children: Cross-sectional survey. Archives of Disease in Childhood, 95(2), 136-140. doi:10.1136/ adc. 2009.171660

Hjern, A., Alfven, G., \& Östberg, V. (2008). School stressors, psychological complaints and psychosomatic pain. Acta Paediatrica, 97(1), 112-117. doi:10.1111/j.1651-227.2007.00585.x

Kanner, A. D., Coyne, J. C., Schaefer, C., \& Lazarus, R. S. (1981). Comparison of two modes of stress measurement: Daily hassles and uplifts versus major life events. Journal of Behavioral Medicine, 4(1), 1-39. doi:10.1007/BF00844845

Lipp, M. E. N. (2000). O stress da criança e suas consequências. In M. E. N. Lipp (Ed.), Crianças estressadas: Causas, sintomas e soluções (pp. 13-42). Campinas, SP: Papirus.

Lipp, M. E. N., Arantes, J. P., Buriti, M. S., \& Witzig, T. (2002). O estresse em escolares. Psicologia Escolar e Educacional, 6(1), 51-56. doi:10.1590/S1413-85572002000100006

Lipp, M. E. N., \& Lucarelli, M. D. M. (2008). Escala de Estresse Infantil (ESI): Manual. São Paulo, SP: Casa do Psicólogo.

Marôco, J. (2011). Análise estatística com o SPSS Statistics $\left(5^{\text {th }}\right.$ ed.). Pero Pinheiro, Portugal: Report Number.

Marturano, E. M. (2008). Tensões cotidianas na transição da primeira série: Um enfoque de desenvolvimento. Psicologia em Estudo, 13(1), 77-85. doi:10.1590/S1413-73722008000100010

Marturano, E. M., \& Gardinal, E. C. (2008). Um estudo prospectivo sobre o estresse cotidiano na $1^{\mathrm{a}}$ série. Aletheia, 27(1), 81-97. Retrieved from http:// pepsic.bvsalud.org/scielo.php?pid=S141303942008000100007\&script=sci_arttext

Masten, A. S., \& Coatsworth, J. D. (1998). The development of competence in favorable and unfavorable environments: Lessons from research on successful children. American Psychologist, 53(2), 205-220. doi:10.1037/0003066X.53.2.205

Matthews, J. S., Kizzie, K. T., Rowley, S. J., \& Cortina, K. (2010). African Americans and Boys: Understanding the literacy gap, tracing academic trajectories, and evaluating the role of learningrelated skills. Journal of Educational Psychology, 102(3), 757-771. doi:10.1037/a0019616

National Institute for Educational Studies and Research "Anísio Teixeira". (2009). Provinha Brasil: Kit Teste 2009. Brasília, DF: Author. Retrieved from http://provinhabrasil.inep.gov.br 
Pacanaro, S. V., \& Di Nucci, E. P. (2005). Stress infantil: Uma comparação entre meninos e meninas do ensino fundamental. Argumento, 7(13), 65-76. Retrieved from http://www.portal. anchieta.br/revistas-e-livros/argumento/pdf/ argumento13.pdf

Pereira, M. T., Marturano, E. M., Gardinal-Pizato, E. C., \& Fontaine, A. M. G. (2011). Possíveis contribuições da educação infantil no desempenho e competência social de escolares. Psicologia Escolar e Educacional, 15(1), 101-109. doi:10.1590/S1413-85572011000100011

Rende, R. D., \& Plomin, R. (1992). Relations between first grade stress, temperament, and behavior problems. Journal of Applied Developmental Psychology, 13(4), 435-446. doi:10.1016/01933973(92)90011-6

Robbers, S. C. C., Bartels, M., van Oort, F. V. A., van Beijsterveldt, C. E. M., van der Ende, J., Verhulst, F. C., ...Huizink, A. C. (2010). A twin-singleton comparison of developmental trajectories of externalizing and internalizing problems in 6- to 12-year-old children. Twin Research and Human Genetics, 13(1), 79-87. doi:10.1375/twin.13.1.79

Silver, R. B., Measelle, J. R., Armstrong, J. M., \& Essex, M. J. (2010). The impact of parents, child care providers, teachers, and peers on early externalizing trajectories. Journal of School Psychology, 48(6), 555-583. doi:10.1016/j. jsp.2010.08.003
Tanganelli, M. S. L., \& Lipp, M. E. N. (1998). Sintomas de stress na rede pública de ensino. Estudos de Psicologia (Campinas), 15(3), 17-27.

Trivellato-Ferreira, M. C., \& Marturano, E. M. M. (2008). Recursos da criança, da família e da escola predizem competência na transição da $1^{\text {a }}$ série. Revista Interamericana de Psicologia, 42(3), 549-558. Retrieved from http://pepsic. bvsalud.org/pdf/rip/v42n3/v42n3a15.pdf

Vanaelst, B., De Vriendt, T., Huybrechts, I., Rinaldi, S., \& De Henauw, S. (2012). Epidemiological approaches to measure childhood stress. Paediatric and Perinatal Epidemiology, 26(3), 280297. doi:10.1111/j.1365-3016.2012.01258.x

Vilela, M. V. (1995). Sintomas e fontes de stress em uma amostra de escolares da $1^{a}$ a $4^{a}$ série (Unpublished master thesis, Pontifícia Universidade Católica de Campinas, Campinas, SP, Brazil).
Recebido: $17 / 09 / 2015$

$1^{a}$ revisão: $16 / 03 / 2016$ Aceite final: 18/03/2016 